\title{
Out of the Shadow and Into the Spotlight - The Development of Distance Teaching in Norwegian Higher Education
}

\author{
Gunnar Grepperud \\ Anne Støkken \\ Jan Toska
}

\section{Distance Teaching - Some Education Policy Traits}

On October 4, 1914, The Norwegian Correspondence School (NKS) accepted its first student, a woman, who, for a fee of NOK 10, registered for two courses (Amdam and Bjarnar, 1989). Seventy-five years later, distance education has become an important part of Norwegian higher education. However, there are several reasons why distance teaching did not gain acceptance in Norwegian higher education earlier. One of is the well-known skepticism of distance teaching as a strategy, the other was the adoption of other modes of making higher education accessible to more people, such as offering part-time studies and decentralized study programmes in locations without higher education institutions. In Norway, because geography has been more of an obstacle than social class, might help explain the greater focus on building traditional education institutions during this period (Støkken 1999).

Early in the 1990s, we can talk to a certain degree of a change of climate or attitudes towards distance education within higher education circles. This change in attitude was initially found in the Ministry of Education and with a few visionary university and college leaders. However, by the late 1990s, favourable attitudes towards distance education had spread to an increasingly larger number of faculty members, as indicated by a substantial number of distance teaching programmes that were being developed. Hence, it can now be claimed that distance teaching has moved out of the shadows and into the spotlight.

Although running the risk of historical simplification, we claim that the beginning of "the new spring in distance teaching" can be connected to two pivotal events at the end of the 1980s. These events may be understood both as visible developments and as essential prerequisites for further developments in the field.

The first is closely connected to the ICDE 14th World Conference in Oslo in 1988, and more specifically to the opening lecture given by the then Prime 
Out of the Shadow and Into the Spotlight - The Development of Distance

Minister, Gro Harlem Brundtland. Even if she did not announce much in the way of specific efforts underway in Norway, she did suggest visions for this field in general, and for Norway in particular. The other event was the green paper titled: "With full knowledge" (NOU 1988:28 Med viten og vilje), also know in Norway as the Hernes Report. At the time, there was a growing optimism outside education circles, which emphasized the ideal of lifelong learning and education as a way of life rather than a particular phase of life. Within this context, distance teaching was discussed as a viable strategy strongly influenced by advances in information technology (IT).

The Hernes Report indicated that distance teaching would be both a less expensive and qualitatively better form of education than what was being offered by traditional institutions at that time. So far it has been difficult to determine if these expectations have come true. However, we can with some certainty say that distance teaching has not proven to be inferior to so-called regular education (e.g., SOFF's surveys below). As to the expectations of "inexpensive study programmes," the central authorities have expressed other and more realistic assessments.

\section{The Structure of Distance Teaching in Norwegian Higher Education - The Establishment of SOFF}

Report to the Parliament (Storting) no. 43 (1988-89) titled: "More Knowledge to More People," (Mer kunnskap til flere) clearly signaled that the existing higher education institutions should be used for distance teaching. There was no wish to establish a separate open university for a number of reasons. First, the central authorities considered such a solution fairly unrealistic both in terms of finances and expertise. Second, importance was attached to the creation of a national network between universities and colleges, one that would resolve some of the major problems facing Norwegian higher education at that time. The idea was that by dividing the work among the educational institutions, teaching expertise could be concentrated in a few strong environments. At the same time, learning opportunities could be distributed, thereby allowing access to higher education in various subjects regardless of students' place of residence. Distance teaching would play an important role in this respect. A third reason the concept of an open university was not accepted, was that G. Hernes, the Norwegian Minister of Education at the time, did not approve the idea of expanding the number of universities.

As an alternative to an open university, a small coordinating unit - SOFF - was instead established in 1990 to create an electronic knowledge network. In the Parliamentary (Storting) report No. 43 (1988-89), the rationale for establishing a state agency for, what was then called: "Distance Teaching on a Higher Level in Norway," was the need for a national agency to handle national tasks, to stimulate Norwegian universities and colleges to become active in this field, and

International Review of Research in Open and Distance Learning 
Out of the Shadow and Into the Spotlight - The Development of Distance Teaching in Norwegian Higher Education

to evaluate and coordinate the operations that had already been launched or which would be launched.

The power and authority the national agency would have over the educational institutions would mainly rest on the allocation of project funds and on professional expertise that might enable institutions and experts to join together. A clear division of labour between the agency and the educational institutions was planned. SOFF would stimulate and coordinate, while the educational institutions would develop and offer distance teaching programmes.

The Committee on Education and Church Affairs of the Norwegian Parliament found it natural that such an agency would be located in Northern Norway, "where this type of education has had or will have particularly great importance." Critics nevertheless interpret the Northern Norway location from another standpoint - regional considerations were far more important than a major effort to develop the field of distance teaching (Eide, 1996, pg. 61). SOFF was finally established and its secretariat was located in Tromsø. The Ministry also designated seven so-called hubs for distance teaching, where it was originally envisioned that the bulk of distance teaching programmes would originate. Right from the start, SOFF disagreed that distance teaching should be restricted to these seven hubs and in 1993 proposed that the scheme of using hubs be abandoned. In practice, the scheme with seven hubs in distance teaching has lost all importance. On its own initiative, in 1995, SOFF established an informal network for the exchange of experience and contact: The National Distance Teaching Network.

\section{Development Strategy and Education Policy}

The 1990-94 period was an active, turbulent and eventful time for higher education in Norway. Important events during this period included a vast increase in the number of students enrolled in higher education, restructuring of the state college sector, and the establishment of common legislation and regulations for state universities and colleges. In this picture, not only was distance education a relatively marginal activity, it was a completely new activity for most higher education institutions. During the first half of the 1990s, and functioning on a fairly satisfactory level with respect to its mandate and budgetary framework, SOFF laid the groundwork for later major developments. This gradual development, however, was not accompanied by increased government funding.

From 1995 to 1997, new national units, which partly overlapped SOFF's field of operations, were established and the central authorities focused more on Information and Communication Technology (ICT) in ordinary education than on distance education. In spite of this, the field progressed rapidly, largely due to the growth of the Internet and the growing emphasis on the role of universities and colleges as institutions for lifelong learning. During the last five years,

International Review of Research in Open and Distance Learning 
Out of the Shadow and Into the Spotlight - The Development of Distance

the interest and activity levels of distance teaching and flexible education have increased greatly. This growth occurred in spite of the absence of clear direction in education policy and initiatives for a unified policy, a fact so striking we refer to it as an "educational policy lag," where the central authorities have lagged significantly behind developments.

In recent years, the most important education policy initiative has concerned further and continuing education. This initiative, the so-called Competence Reform, has mainly targeted developing theoretical and practical competencies of the working population. In the proposed budgets for 1999 and 2000, the Ministry signaled expectations that SOFF and higher education should contribute to realising the intentions of the Competence Reform through their activities. These signals suggest that the central authorities are now more aware of the increased importance of distance teaching or flexible learning in higher education. (Flexible learning is the new buzzword in Norway, including both distance education and ICT-supported campus education).

In spite of indications of a more active education policy, much work remains before the educational policy lag can be overcome. The following educational policy challenges may be mentioned:

- Various public initiatives are needed to stimulate the use of ICT both in ordinary and distance teaching, in order to enhance quality and to better orient users.

- Evaluation, research and development, learning from experience, and competenceraising activities in flexible learning in higher education, must be significantly strengthened.

- Relationships between the fields of higher education and the adult education, and the actors involved in the two traditionally separate fields, must be further clarified.

- Universities and colleges must be provided with more freedom, allowing them to satisfy new demands for restructuring and adapting study programs for users. Higher education's degree of market orientation must also be balanced in relation to the fact that universities and colleges have a long-term duty to society in preserving, developing and passing on research-based knowledge.

- Further development of the field depends greatly on the policies and efforts of individual educational institutions. An interesting feature in this context is that the administrative officers of many Norwegian universities and colleges recognise the great strategic importance that distance teaching and flexible learning might have for their own institutions in the future. Much of this understanding is still connected with the rhetoric and positioning through various loose cooperation projects. To stay on top of 
Out of the Shadow and Into the Spotlight - The Development of Distance

Teaching in Norwegian Higher Education

developments in this area, poses new challenges for central authorities and SOFF.

\section{The Educational Challenges - From Distance Teaching to Flexible Education}

SOFF and higher education initially faced three educational challenges: one, expectations of increased recruitment of adults; two, the development and testing of study models; and three, the use of ICT. Motivating universities and colleges to take this task seriously was another major challenge. From SOFF's perspective, distance-teaching activities at the educational institutions should serve a "double benefit goal." The work performed by scientific personnel with distance education would raise the quality of teaching at the institution, both by raising the competence of their teaching staff and by utilising teaching aids. The development during the 1990s supports these assumptions.

\section{ICT as a Basic Condition and Measure}

In the early1990s, when information and communication technology was adopted for general use, distance education expanded its repertoire. This not only applied to limited pilot projects, but also to regular distance education programmes. Even early in the 1980s, Norwegian universities and colleges tested a wide range of technological possibilities, including the telephone, satellite-based transmissions, computer technology, and video conferencing. SOFF's own reviews show that during the 1990s, institutions of higher education (in some cases in cooperation with the autonomous distance teaching institutions) tested a variety of relevant technological alternatives. This developmental activity appears in no way to lag behind the international scene. After many study visits abroad, it is interesting to note that Norway is fully up to the standards of the rest of the world.

While ICT has been an important driving force, it also has been dysfunctional in some areas. One of the most prominent features of the ICT development so far, is that it is accompanied by rhetoric that typically promises much more than it can deliver. Haugsbakk (2000) offers a number of critical remarks on the exaggerated enthusiasm and grand visions that are typical of this field and points to a number of interesting aspects, including the lack of historical awareness in current debates and developments, prominent revolutionary rhetoric, restricted technical or technological perspectives, and a conscious use of biased concepts that explicitly and implicitly communicate positive values and qualities in a learning context.

International Review of Research in Open and Distance Learning 
Out of the Shadow and Into the Spotlight - The Development of Distance

\section{Teaching Models}

Generally, the so-called "classic" distance education model, as practiced in Open Universities in other countries such as in the UK, Germany and Canada, for instance, has been somewhat restricted in Norwegian higher education. This was expressed on pages 42 and 43 of the Parliamentary (Storting) report No. 40 (1990-91) "From Vision to Work" (Fra visjon til virke):

Distance teaching should be a supplementary element of the teaching programmes. Development of education programmes based solely on distance teaching, as practiced by some open universities in other countries, is so far not pertinent for institutions of higher education in Norway.

Thus the main model in Norway has been a combined form of distance teaching. Included as a smaller or larger part of a comprehensive plan comprising selfstudies (partly by means of specially adapted electronic and paper-based teaching aids) are: face-to-face meetings, two-way synchronous and asynchronous dialogues among participants, and in some cases, activities and developments tied to a student's local community or workplace. This emphasis on combined models in higher education may be linked to the fact that Norwegian higher education has more experience with part-time and decentralized programmes, and that these programmes have revealed the importance of meetings among students for a number of reasons. Still others claim that the emphasis on combined teaching programmes may be understood as an attempt by established academia to wrest some degree of control over a new and unknown field (Støkken, 1999).

With the development of web-based programmes, a growing number of studies, including those on a higher level, will approach the classic distance education model. The major challenge of such a model is to maintain the qualities connected to the academic dialogue as they appear in the good seminar situation. So far the experiences appear slightly divided. A high number of current programmes appear more to be electronic correspondence courses than integrated, holistic study environments.

The methods and strategies adopted by distance education are often based on the idea that distance is a problem - e.g., that compensation is needed for the problems that arise when the involved parties are not together in the same place or at the same time. However, distance may also be considered an opportunity, primarily because it allows for exploitation of several different learning arenas. Distance education offers better opportunities to bring learning arenas and similar knowledge forms together. For example, the teacher education project FUTURE at the University of Troms $\varnothing$, was based on a flexible model to better exploit teaching practice as a learning arena and to establish better connections between a student's academic learning and practical experiences (Grepperud, 1997; Thorp, 1999).

International Review of Research in Open and Distance Learning 
Out of the Shadow and Into the Spotlight - The Development of Distance

\section{From Product to Process Orientation}

Throughout the first half of the 1990s, Norwegian distance education activities typically clung to an extended product-oriented model. This development was inspired by emerging technological possibilities, by the belief that an increased

number of teaching aids would reinforce learning, and by inspiration from developments in international distance education. This production model may, in one sense, be claimed to be the most sophisticated form of distance teaching based on industrial (Peters, 1993) or Fordian thinking (Grepperud 1997; Farnes, 1993; Campion, 1995). The production model may be said to base its operations on a paradox. While its teaching aids promote openness with respect to accessibility and thus allow students to control their own study situation, it is fairly closed when it comes to content, the view on knowledge, and on the learning process itself. Experiences with this model are somewhat ambiguous (Wilhelmsen, 1996). To the extent that assessments have been carried out for such programmes in a Norwegian context, no evidence can be found either that the integration of a number of media/teaching aids or expensive media productions in themselves strengthen learning outcomes.

Throughout the last half of the 1990s, there were initiatives to use media more effectively and to apply more process-oriented thinking with regard to distance education. This approach attaches much importance on creating a social learning environment and is linked to a number of issues: learning theory re-orientation in the direction of constructivism; orientation towards greater individualism; flexibility and user control; and the transition from second-generation to thirdgeneration technology, which implies more and better opportunities for interaction between actors in teaching and learning processes. These approaches, to a certain degree, have revitalized interest in established learning theorists such as Piaget and Vygotsky in a distance education context. Thus we can see in these developments in the field of distance education, an increased emphasis on learning theory that has been influenced by technical possibilities.

Even though ICT has been used throughout the 1990s for communication between individuals (both synchronously and asynchronously), Norwegian academic discourse and theoretical reflection on ICT has, to a limited extent, focused more on its pedagogical use. So far it appears that with regards to research and assessment, too much time has been spent on looking for reasons why activity levels are so low with technology itself. Not only has such an approach yielded poor results, in our opinion this approach represents a flawed and simplistic view of complex teaching and learning processes.

\section{Media Innovation and Method Tradition}

Referring to teaching connected to adult learning in general, Paulsen has documented that within web-based teaching, no methods are found that are not 
Out of the Shadow and Into the Spotlight - The Development of Distance

also used in an adult education context, and that the choice of methods used in web-based education is less varied than what is found in other adult education settings (Paulsen, 1998).

Paulsen's conclusion also seems to apply to the teaching forms that have been used for distance teaching in general. Generally, the same teaching methods persist even if the context is changed from local to distance and/or ICT-supported teaching. Such an acknowledgement contrasts with the claim that distance teaching virtually, by definition, means an education paradigm shift. Nonetheless, it is important to underline that the use of traditional teaching principles and methods does not mean that the education programmes are of poor quality. Such stereotyping of the educational discussion can be found among the most enthusiastic and uncritical advocates for the use of ICT.

Our experience suggests that an interesting approach may be to redefine the expectations for new pedagogy or new didactics. Instead of referring to qualitatively new forms of teaching and learning (i.e., the paradigm shift thesis), it may be more productive to focus on measures to implement general and familiar didactic principles within a new context.

\section{A Field Undergoing Change: New Actors - New Relations}

During the 1980s, Norwegian higher education has become a composite and complex field. When SOFF arrived on the scene in 1990, it appeared reasonable to speak about a dual-track system for knowledge distribution in higher education. One consisted of a large network of public universities and colleges; the other a small network of public and private actors that included distance education institutions, adult education organisations, and The Norwegian Broadcasting Cooperation (NRK). The actors in these two tracks had widely divergent interests and different conditions, both organisationally and financially, so much so they may also be understood as different social fields (Bourdieu and Wacquant, 1993). When applying such a "field" perspective to higher education, it also becomes clear that there was a ranking order between the two sub-fields; those who were working with distance education were struggling to have their methods perceived as equally good as those of traditional education (Støkken 1999).

When SOFF was about to launch its operations, the situation was one where the various suppliers in these two networks were developing overlapping domains and activity areas. They were increasingly targeting the same groups, attempting to satisfy the same needs, offering similar services, and/or targeting the same sources of financing. The situation was one of intensifying competition, which in many cases was tackled by means of new network formations.

International Review of Research in Open and Distance Learning 
Out of the Shadow and Into the Spotlight - The Development of Distance

Teaching in Norwegian Higher Education

\section{New Network Formations}

When SOFF commenced operations, many cooperative projects and small networks had already been established. Later, such network formations became more and more common. It would not be unfair to speak about an explosion of new - more or less hybrid - organisational designs that partly transcend the public-private boundary. This has come about in part on the initiative of the institutions, and within distance education this has also been an expression of SOFF's strategic intentions.

We may, in principle, distinguish between (at least) two network types. One is based on complementary - i.e., the actors have different resources as a basis for a balanced trade among themselves. Cooperation between distance education institutions (which supply and distribute teaching materials and organise distance teaching), adult education institutions (such as local course arrangers), and the traditional education institutions (with professionals and the right to arrange examinations), are examples of this type. The other type of cooperation is based on greater equality of resources and may, for example, concern different educational institutions. Examples may be large national distance education programmes where one institution is in charge of project management, but is cooperating with others based in their respective fields of expertise. However, there is a plethora of tensions in this field connected to the autonomy of institutions and their reluctance to be subordinate to others.

\section{The Public-Private Relationship}

As demonstrated in the Parliamentary (Storting) report No. 43 (1988-89), during SOFF's initial phase, the relationship to private actors was characterised by a higher degree of visibility and acceptance than had previously been the case, particularly concerning higher education. Private actors have always been included in the practical work regarding establishing and operating SOFF. They have always sat on the board of SOFF, and they have been represented in strategy groups working on assignment from SOFF (SOFF, 1993 and SOFF, 1997).

There has also been cooperation between public and private institutions in the many small and large networks established around specific study programmes based on distance teaching. These networks have functioned well primarily due to the fact that Norway's public education institutions have undergone changes that have made them more market oriented. We can see evidence of this, for example, in a more explicit wish on the part of educational institutions to channel their assignment operations via external foundations or joint-stock companies.

This dawning market orientation really took off in 1997, when the entire estab-

International Review of Research in Open and Distance Learning 
Out of the Shadow and Into the Spotlight - The Development of Distance

lished academia were challenged by a proposal by the Norwegian Employer's Confederation (NHO) to establish a Norwegian Open University. This proposal made distance teaching a visible alternative and, for the first time, the subject of education policy discussion in which major portions of the sector became engaged. It is also interesting because the initiative signaled that distance teaching is now a generally acceptable education policy scheme in higher education.

What now appears to be happening, is that the Norwegian network concept is being instantiated and designed from below, probably in a far more binding manner and with closer relations than previously envisioned when this network was first launched. It also appears that universities and colleges are confirming their role as "suppliers" in a knowledge market. A recent initiative for creating a Norwegian University Network for Lifelong Learning appears to be based on an understanding of higher education both as a "mixed economic" and a "mixed administrative" system. This mixture of public and private sectors, market and hierarchy, has led to new and more hybrid forms and more institutionalised forms of distance teaching in higher education.

\section{From Enthusiasts to Institutionalization}

In the early 1990s, distance teaching in the educational institutions was promoted and conducted by enthusiasts. These people believed in this new arena of work and were excited to be a part of it. Over time, enthusiastic activity has given way to a firmer organisational basis as evidenced by an office or department at many institutions. In some cases, it may even have been set up as an external operation altogether and combined with further and continuing education. Up to this time, it has been difficult to determine what type of organisational design will lead to a better institutional form of distance teaching and flexible learning. That staff may wish to continue to retain such assignments as supplementary jobs may indicate that these operations will be organised in external units with a greater degree of independence. However, such wishes may also be seen as an attempt by the traditional sector to keep the new teaching forms somewhat off to the side of the old ones, if only to avoid more fundamental and comprehensive restructuring. One can only expect that when traditional lectures or classroom instruction are no longer the only cornerstone of the higher education system, the current work organisation and administrative structures will come under scrutiny again. Not all educational institutions are ready for that yet.

Perhaps the most basic barrier in the established system is tied to the distinction between teaching and research. Work with new teaching models takes time. The handicap of distance teaching is that it must compete for employee time and interest in research. Research is what primarily provides status and promotion possibilities in the system.

International Review of Research in Open and Distance Learning 
Out of the Shadow and Into the Spotlight - The Development of Distance

Teaching in Norwegian Higher Education

\section{Flexible Education - A Developing Field}

During the 1990s, two decisive factors made distance education more than a marginal activity at Norwegian universities and colleges. First, we have in mind the breakthrough of the Internet and, second, the renewed interest in competence development of the entire adult population. Higher education policies have also changed in the direction of greater market orientation. As a result, it is more probable that these trends will only accelerate.

However, this is not to say that the road ahead is straight and devoid of stumbling blocks - rather it is quite the opposite. The actors in a field growing so rapidly will be faced with a number of difficult considerations and choices. Education policy makers, for example, will have to decide whether they want to exploit distance education and distance teaching as a stage in a more explicit education strategy, or whether they want to leave it to the actors in the current education market to handle this development alone.

\section{Literature}

Amdam, R.P. and Bjarnar, O (1989). NKS en bedrift i norsk skole [NKS a company in the Norwegian school]. Oslo: NKS-Forlaget.

Boyesen, E. (1964). Norsk Korrespondanseskole gjennom 50 àr [The Norwegian Correspondence School through 50 years]. Oslo: NKS.

Bourdieu, P. and. Wacquant, L.J.D. (1993). Den kritiske ettertanke [The critical after-thought]. Oslo: Samlaget.

Brundtland, Gro, H. (1988). Developing Distance Education - the Broady Lecture at the 14th World Conference on Distance Education, Oslo, 12 August 1988 .

Campion, M. (1995). The Supposed Demise of Bureaucracy: Implications for Distance Education and Open Learning - More on the Post-Fordism debate. In Distance Education Vol. 16, No. 2.

Eide, K. (1996). Samfunnsendring og livslang læring [Social Change and Lifelong Learning]. In Tøsse.S (ed): Fra lov til reform.[From Act to Reform]. Trondheim: NVI.

Farnes, N. (1993). Modes of Production: Fordism and Distance Education. In Open Learning. Vol. 8, No. 1.

Grepperud, G. (1996). SOFF and the National Distance Education Network Background, Organizational and Didactical Experiences. In George J.; Støkken, A.M.; and Nyhlen B. (Eds.) Distance Education in Norway and Scotland. Ed- 
Out of the Shadow and Into the Spotlight - The Development of Distance

inburgh, Scotland: John Donald Publishers.

Grepperud, G. (1997). Lærerutdanning pà nytt spor - FUTURE-prosjektets profil og forankring [Teacher education on a new track - the FUTURE project's profile and basis]. In Grankvist, R. et al.(Ed). Klasserommet i sentrum. Festskrift til \&\#197;smund Strømnes. Trondheim: Tapir.

Grepperud, G. (1999). Samarbeid mellom Folkeuniversitetet og høgre utdanningomfang, aktivitet og relasjon [Cooperation between Folkeuniversitetet and higher education - scope, activity and relation]. Forskningsrapport nr. 44. Høgskolen i Lillehammer.

Haugsbakk, G. (2000). Interaktivitet, teknologi og læring [Interactivity, Technology and Learning]. ITU report. Oslo.

KUF (1988-89). Innstilling [Recommendations] S. 267 (1988-89).

KUF (1988-89). Mer kunnskap til flere [More Knowledge to More People]. (Report to the Storting no. 43.) Oslo.

KUF (1988). pg. 28. Med viten og vilje [With Full Knowledge and Will]. Oslo: NOU.

KUF (1990-91). Fra visjon til virke [From Vision to Work]. (Report to the Storting no. 40.) Oslo.

KUF (1996). IT i norsk utdanning - 1996-99 [IT in Norwegian Education - Plan for 1996 - 99].

KUF (1997). pg. 25. Ny kompetanse [New Competence]. Oslo: NOU.

KUF (1997-98). Kompetansereformen [The Competence Reform]. (Report to the Storting no. 42.) Oslo.

KUF (1999). pg.18 Organisering av oppdragsvirksomhet [The Structure of Assignment Activities] Oslo: NOU.

Mason, R. (1995). Using Communications Media in Open and Flexible Learning. London: Kogan Page.

Paulsen, M.F. (1998). Teaching Techniques for Computer-Mediated Communication. University Park, PA. PennState University: The Graduate School.

Peters, O. (1988). Distance teaching and industrial production: a comparative interpretation in outline. In Sewart, D. et al. (Eds.) Distance Education International Perspectives. London: Routledge.

Rekkedal, T. and Paulsen, M. F., (1992). Den elektroniske høgskolen, EKKO prosjektet, del III [The Electronic College, the EKKO project, part III]. SEFU/NKI. 1009 . Oslo. 
Out of the Shadow and Into the Spotlight - The Development of Distance

Sewart, D. (1988). Distance Teaching: A Contradiction in Terms? In Sewart, D. et al., (Eds.) Distance Education International Perspectives. London: Routledge.

SOFF (1993). Fra prosjekt til permanens? Erfaringer med fjernundervisning i norsk høgre utdanning [From Project to Permanence? Experiences with distance teaching in Norwegian higher education]. Report No. 6

SOFF(1993). Det nasjonale kunnskapsnettet [The National Knowledge Network]. Report No. 5

SOFF (1997). Utviklingen av fjernundervisningstilbudet i norsk høgre utdanning fram mot 2005. Innstilling fra utredningsgruppe nedsatt av Sentralorganet for fjernundervisning pà universitets- og høgskolenivà [The Development of the Distance Education Programme in Norwegian Higher Education towards 2005. Recommendations from a study group convened by the Norwegian Agency for Distance Teaching on the University And College Levels]. Report No. 2

Studiekvalitetsutvalget (1990). Studiekvalitet [Studies Quality]

Støkken, A.M. (1999). Det usynlige Akademia. Om fjernundervisning i høyere utdanning [The Invisible Academia. On Distance Teaching in Higher Education]. Troms $\varnothing$ : The University of Troms $\varnothing$.

Thorp,V. (1999). Langt borte og nesten der. Fleksibel lærerutdanning [Far Away and Almost There: flexible teacher education]. Oslo: UNIKOM Report No. 2

Yanay, U. (1989). Reactions to Domain Overlap. In Administration \& Society. November.

Wilhelmsen, L. S. (1996). Integrating Distance and Traditional Education at a University. In George, J., Nylehn, B., Støkken, M. (Eds.) Distance Education in Norway and Scotland: Experiences and Reflections. Edinburgh: John Donald Publishers.

Citation Format

Grepperud, Gunnar, Støkken, Anne Marie \& Toska, Jan Atle (January, 2002) Out of the

Shadow and Into the Spotlight - The Development of Distance Teaching in Norwegian

Higher Education. International Review of Research in Open and Distance Learning: 2, 2.

http://www.icaap.org/iuicode?149.2.2.11 